"NOTICE: this is the author's version of a work that was accepted for publication in FISHERIES RESEARCH. Changes resulting from the publishing process, such as peer review, editing, corrections, structural formatting, and other quality control mechanisms may not be reflected in this document. Changes may have been made to this work since it was submitted for publication. A definitive version was subsequently published in John Curtis, Pike (Esox lucius) stock management in designated brown trout (Salmo trutta) fisheries: Anglers' preferences, Fisheries Research, Volume 207, November 2018, Pages 37-48, https:// doi.org/10.1016/j.fishres.2018.05.020 " 


\title{
Pike (Esox lucius) stock management in designated brown trout (Salmo trutta) fisheries: Anglers' preferences
}

\author{
John Curtis ${ }^{\mathrm{a}, \mathrm{b}, *}$ \\ ${ }^{a}$ Economic and Social Research Institute, Sir John Rogerson's Quay, Dublin, Ireland \\ ${ }^{b}$ Trinity College Dublin, Dublin, Ireland
}

\begin{abstract}
The sustainable management of fisheries is increasingly as much about people as it is about stock management and an important prerequisite for managing stakeholder disagreement is an understanding of each party's position and perspective. In Ireland pike stocks are actively managed within specific fisheries for the purpose of protecting brown trout stocks. Associated public discussion is increasingly polarised with a clear message that trout anglers favour and pike anglers oppose such management intervention. A first step towards successfully managing the tension between all stakeholders is a better understanding of the broad spectrum of anglers' views. Latent-class site-choice models are estimated with choice experiment data to reveal information on anglers' preferences with the data collected via an online survey from 341 members of a recreational angling research panel. Several policy relevant lessons arise from the analysis. First, anglers' preferences are not homogeneous, either among pike or trout anglers. Angler stakeholder groups cannot reasonably attest to represent all pike or trout anglers. There are multiple distinct classes of anglers with quite different preferences on pike stock control as well as other fishery attributes, such as bag limits and catch rates. Second, while anglers have strong preferences across a number of fishery attributes (e.g. catch rates, pollution, invasive weeds, etc.), pike stock control is the predominant attribute affecting anglers' behaviour. Third, among trout anglers there is a sizeable majority opposed to the maintenance of existing pike stock control measures, which is at odds with a vociferous public campaign led by trout angling representative organisations. The preferences of this 'silent' majority reflect the fact that approximately 2 -in- 5 trout anglers also fish for pike. In general, the research helps inform fishery management decisions, dispelling the idea of a clear dichotomy between pike and trout anglers and instead illuminates the complexity of anglers' preferences.
\end{abstract}

Keywords: angling, stock control, conflict, latent class

\section{Introduction}

Stock management is a regular feature of recreational fisheries, through habitat enhancement, stocking programmes and harvesting (Arlinghaus, 2006; Patrick et al., 2006; Marco-Rius et al., 2013; Arlinghaus et al., 2014; Thuesen et al., 2011; Schaufler et al., 2015). Stocking programmes often are based on the simple premise that stocking increases fish abundance, which leads to higher catch rates and more satisfied anglers (Loomis and Fix, 1998; Patterson and Sullivan, 2013), an idea that has been demonstrated as flawed under certain circumstances (Schultz and Dodd, 2008; Patterson and Sullivan, 2013). Active stock management is generally in response to declines in (wild) fish stocks, which can be related to recreational fishing or its management practices (Arlinghaus et al., 2002), as well as a symptom of a wide range of other activities that damage aquatic ecosystems (Cowx et al., 2010; Craig, 2016). Structural and functional changes in fish stocks and aquatic ecosystems can arise due to recreational fishing pressures (Lewin et al., 2006; Johnston et al., 2013; Post, 2013) and stocking itself can have unintended impacts (Lorenzen, 2005, 2008; Larsen et al., 2005; Støttrup and Sparrevohn, 2007).

\footnotetext{
${ }^{*}$ Corresponding author

Email address: john. curtis@esri.ie (John Curtis)
} 
Anglers are a heterogeneous group and multiple angler cohorts have been identified across many fisheries (Connelly et al., 2001; Arlinghaus and Mehner, 2005; Hutt and Bettoli, 2007), with various angler cohorts seeking different fishing experiences (Fisher, 1997). Many anglers support stocking programmes (Aas and Kaltenborn, 1995; Arlinghaus and Mehner, 2005) but anglers often comprise both vocal stakeholder groups and a 'silent majority' with conflicting positions on the merits of stock management (Hunt et al., 2010, 2014). Specifically, a number of papers show that angler participation or fishing effort increases when stock management increases the population of target fish (Loomis and Fix, 1998; Ready et al., 2005; Dabrowska et al., 2014), while Arlinghaus et al. (2014) suggest that preferences on stocking programmes is related to changes to fishing quality, whereas Fayram et al. (2006) find that in some instances increased effort can be attributed to the act of stocking, independent of any impact it may have on fish population size. In essence, anglers respond to perceived, as well as actual, fishing conditions. These responses to stocking may reflect underlying preferences for catch experiences believed to be affected by stocking (Teisl et al., 1996). Other angler cohorts can oppose stocking, as they prefer catching wild rather than stocked fish (Hunt et al., 2010; Churchill et al., 2002; Olaussen and Liu, 2011).

Within specific fisheries, stock management decisions have the potential for conflict, though Charles (2001) suggest that conflict tends to be the rule rather than the exception in fisheries due to their complexity and dynamic nature, and because of the many interactions among ecosystems, humans and institutions. The current study is a case in point. Within designated wild brown trout (Salmo trutta) fisheries in Ireland pike (Esox lucius) populations are actively managed with the objective of protecting trout stocks. With different angler cohorts targeting pike and trout, conflict inevitably arises, both between angler cohorts and between anglers and the fishery management body. While there is scientific debate whether pike are a native Irish species (Pedreschi et al., 2014; Ensing, 2015) and public debate on the merits of pike population management (Viney, 2015), the objective of the analysis here is to gain a more detailed understanding of anglers' preferences for pike stock management. There is a growing consensus that fisheries management is as much about people management as it is about fish stock management (Wilen et al., 2002; Arlinghaus, 2004; Hilborn, 2007; Arlinghaus et al., 2017). Specifically, Arlinghaus (2005) suggest that one of the most pressing needs in recreational fisheries is the management of 'people conflicts' because such conflicts can hamper any progress towards sustainability.

A prerequisite for managing conflict is an understanding of each party's position and perspective. Public discussion on pike management is increasingly polarized. Conflict arises between angler cohorts and especially between anglers and Inland Fisheries Ireland, the fishery management body. Inland Fisheries Ireland (www.fisheriesireland.ie) is the statutory agency responsible for inland fisheries and sea angling resources in Ireland with a mission to ensure that angling resources are conserved, managed, developed and promoted for the community and the environment. Inland Fisheries Ireland implements the pike stock control measures in line with an approved pike policy (IFI, 2014). In addition to members of angler organisations on the board of Inland Fisheries Ireland, angling groups, riparian owners, and other stakeholders are consulted as members of the 'National Inland Fisheries Forum'. The forum, whose establishment was provided for in legislation, is a means for Inland Fisheries Ireland to consult and engage with angler stakeholders on fisheries policy. Each of the main angling organisations is invited to nominate two of their members to represent their interests in forum discussions. Pike anglers argue for the abandonment of pike stock management, as specimen sized fish are removed from a number of important lake fisheries. Pike predate on trout and consequently trout anglers are perceived to favour continuation of pike stock management. Most anglers will have a personal view on the existent pike management policy, but similar to angler conflicts elsewhere (e.g. Hunt et al., 2010, 2014) a number of angler representative bodies vociferously argue their perspective on behalf of their affiliated angling club membership. Sustainable management of recreational fisheries requires a transition from single objective management to ecosystem management and aquatic stewardship (FAO, 2012; Arlinghaus et al., 2017) and therefore requires knowledge of fish biology, aquatic ecosystems, as well as all stakeholders. The information base on the human dimensions of recreational fisheries continues to be particularly weak in many European countries (Arlinghaus, 2005) with Ireland being no exception. Arlinghaus (2006) argues that management success in recreational fisheries is primarily dependent on overcoming human obstacles. The focus of the current analysis is the human dimension surrounding this fishery management issue, specifically concentrating on anglers. Greater insight into anglers' preferences, not just for stock management, but also for other characteristics of the fishery such as catch rates, will help better inform future management decisions. 
The objectives of this study are to: (1) understand the preferences of pike and trout anglers for stock management tools; (2) identify the heterogeneity within anglers regarding preferences for pike stock management; and (3) evaluate the impact on angler activity levels of different stock management policy scenarios.

\section{Methods}

\subsection{Choice Experiment}

Stock management decisions are made as part of a suite of decisions on the management of a complex aquatic ecosystem (e.g. on bag limits, etc.). Likewise, where anglers may have views on stock management practices, these views may reflect underlying preferences for catch experiences (e.g. size and abundance) believed to be affected by stock management practices (Teisl et al., 1996). Anglers' real underlying preferences on stock management are likely to be more subtle and complex than the results of a straight poll on whether anglers support stock management or not. Consequently, isolating stock management from the wider management setting is likely to abstract from reality. Instead of a simple poll, we employ a choice experiment (CE) to elicit information on anglers' preferences. A choice experiment survey is a quantitative technique for eliciting preference data based on a realistic hypothetical 'market' for the service or good under consideration. In the current instance the 'market' is a choice between multiple fishing opportunities, which, inter alia, incorporates different stock management options. Survey respondents are asked to state their choice over different hypothetical alternatives, the responses from which allows researchers to determine the relative worth of specified fishery attributes. Choice experiments are increasingly used across a wide range of policy issues, including in recreational fisheries (e.g. Aas et al., 2000; Dorow et al., 2010; Oh and Ditton, 2006; Lew and Larson, 2014).

The Random Utility Model (RUM) of McFadden (1973) is the standard statistical economic framework used to estimate behavioural choice models. Within a RUM model an angler chooses from a number of alternatives (e.g., fishing sites) and selects the one that yields the highest expected utility level on any given choice occasion. Fishing sites comprise a number of attributes (e.g. stock management, average catch, bag limit, etc.), with the level of the attributes differing across choice alternatives. The utility that angler $n$ obtains from site $i$ is

$$
U_{n i}=\beta x_{n i}+\epsilon_{n i}
$$

where $x_{n i}$ is a vector of observed variables, $\beta$ a vector of unobserved coefficients and $\epsilon_{n i}$ is an unobserved error term. An angler chooses among $J$ possible site alternatives. Whenever the utility from angling at site $i$ is greater than the utility from all other sites, site $i$ will be chosen. The RUM model can be specified in different ways depending on the distribution of the error term. Assuming the error terms are identically and independently distributed (iid) extreme value, the RUM model is specified as a conditional logit (CL) (McFadden, 1973). The probability of choosing site $i$ is:

$$
\operatorname{Pr}(i)=\frac{\exp \left(\beta x_{n i}\right)}{\sum_{j=1}^{J} \exp \left(\beta x_{n j}\right)}
$$

The CL model is the workhorse for analysing discrete choice data with many applications (e.g. Parsons and Massey, 2003; Pradhan and Leung, 2004; Provencher and Bishop, 2004; Siderelis et al., 1995). An assumption of the model is that anglers are generally a homogeneous group but there may be good reason why this is not the case. Anglers differ by country of origin, income, social class, as well as other unobserved characteristics and these traits may manifest themselves as differences in preferences. One approach allowing heterogenous preferences is the random parameter logit model, which allows the unobserved coefficients of the model to vary randomly over anglers (Train, 2009). An alternative approach, and the one which we follow here, facilitates variability in preferences across anglers through a mixture or latent class model (LCM). The idea behind the model is that the observed distribution of angler preferences is a mixture of the preferences of a finite number of groups or classes (McLachlan and Peel, 2000). The analyst does not observe directly into which class, $c$, each angler fits, $c \in C$, and class membership must be estimated. The LCM is 
also a mixed logit model and within the latent class structure the probability of angler $n$ within class $c$ choosing site $i$ is similar to equation (2) except that it is conditional on the class $c$ :

$$
\operatorname{Pr}(i \mid c)=\frac{\exp \left(\beta_{c} x_{n i}\right)}{\sum_{j=1}^{J} \exp \left(\beta_{c} x_{n j}\right)}
$$

The expected probability of site $i$ being chosen by angler $n$ is the expected value (over classes) of the class-specific probabilities.

$$
\operatorname{Pr}(i)=\sum_{c=1}^{C} \pi_{c} \operatorname{Pr}(i \mid c)
$$

where $\pi_{c}$ is the membership probability for class $c$. The logit formulation for the probabilities, $\pi_{c}=\exp \left(\theta_{c}\right) /\left(\sum_{c=1}^{C} \exp \left(\theta_{c}\right)\right)$, with $\theta_{C}=0$ is a convenient estimation parametrisation that ensures that the estimated probabilities satisfy the basic properties of a probability: $0 \leq \pi_{c}<1$ and $\sum_{c=1}^{C} \pi_{c}=1$. The log likelihood for the LCM model is

$$
\log L=\sum_{n=1}^{N} \log \left\{\sum_{c=1}^{C} \pi_{c} \frac{\exp \left(\beta_{c} x_{n i}\right)}{\sum_{j=1}^{J} \exp \left(\beta_{c} x_{n j}\right)}\right\}
$$

Both the CL and the LCM models depend on differences among alternative characteristics. Changes in site attributes affect the probability that a site is chosen. The impact of a particular site attribute, including actions such as pike stock management, on the choice decision can be examined by comparing the relative probability of choosing a site, with and without the attribute (or at different levels of the attribute). To investigate how angler attributes such as age, education or skill level are associated with the different angler classes it is possible to specify $\pi_{c}$ as a function of anglers' socio-demographic attributes by letting $\theta_{c}=\gamma_{c} z$, where $\gamma_{c}$ is the parameter for estimation and $z$ represents the socio-demographic variables.

\subsection{Interpreting the model estimates}

The coefficient estimates from the estimated models cannot be interpreted directly. We use two approaches to consider the practical implications of the estimates. Through the estimates of the parameters of the utility function in equation (1) we can derive marginal rates of substitution (MRS) between different attributes. For example, how much of one fishery attribute, such metres of water visibility, anglers are willing to substitute in favour of another fishery attribute, such as average catch rate or pike stock control management. The calculation of MRS between attributes $k=1$ and $k=2$ is given by (6).

$$
M R S_{k_{1,2}}=\frac{\frac{\partial U}{\partial x_{k=1}}}{\frac{\partial U}{\partial x_{k=2}}}=\frac{\beta_{x_{k=1}}}{\beta_{x_{k=2}}}
$$

Another approach to interpret the estimated parameters of the utility function in equation (1) is to compare odds ratios between choice alternatives. Equation (2) is the probability of angler $n$ choosing site $i$, where $x_{n i}$ comprises a vector of site attributes. Consider a second site $h$, where the levels of the site attributes may differ from site $i$, e.g. one site may have an average catch rate of 1 fish more than the other. The ratio of choice probabilities, or odds of selecting site $i$ above site $h$, is

$$
\frac{\operatorname{Pr}(i)}{\operatorname{Pr}(h)}=\frac{\exp \left(\beta x_{n i}\right)}{\exp \left(\beta x_{n h}\right)}
$$

If anglers have strong preferences across the attribute levels that differ between the two sites, the odds ratio in (7) will differ from 1. On the contrary, if anglers do not have strong preferences with respect to the attribute, the odds ratio will not be significantly different than 1 . While MRS is most frequently used in interpreting CE estimates, neither approach is necessarily superior. Both enable the translation of parameter estimates into meaningful results that are useful for informing policy. 


\subsection{Selection of angler sample}

The sample for this study was drawn from a panel of anglers that had volunteered to participate in research surveys. The panel comprises approximately 1000 recreational anglers that fish in Ireland across all target species, not just pike and trout. In Ireland there is no register of anglers or other suitable means (e.g. licence records) to randomly recruit anglers to participate in surveys. Instead, panellists were recruited by a variety of approaches including direct communication with angling representative bodies and angling clubs, posters in fishing tackle shops, publicity in national and local newspapers including notices in 'angling notes', local radio interviews, as well as via social media channels. Panel sign-up occurs via a web-page where contact details, target species, and county location are recorded. Without an angler register there is no means to directly gauge the general representativeness of the angler panel. However, a random omnibus survey of the adult population conducted in 2015, which included questions on angling, facilitates representativeness checks based on age. Specifically focusing on pike and trout anglers, younger age groups (i.e. 15-34 years) are under-represented by approximately half in our samples (both trout and pike) while the 45-65 age group are over-represented by approximately double. The $35-44$ and $66+$ age groups are broadly representative, so fear of a 'grey digital divide' associated older respondents not having computer or internet access is not evident in this instance (Morris, 2007). Through estimation of $\gamma_{c}$, as defined in the previous section, we investigate whether angler attributes, including age, are important explanatory variables of anglers' expressed choices. The estimates of $\gamma_{c}$ are discussed later, but it is noteworthy at this point to state that the probability of an angler being a member of any particular latent class category is not related to their age, which provides support to the view that any bias associated with the sociodemographic representativeness of the sample is not reflected in the model's results.

While there is no means to directly gauge the representativeness of the angler panel, the panel does have a broad distribution of anglers both by geographical location and target species. The use of online methods to conduct surveys has been called into question in the past due to the likelihood of potential sampling bias (Fleming and Bowden, 2009) but no single method of survey administration has been proven superior to any other (Champ, 2003). An advantage of the angler panel and online surveys over traditional survey methods include the low costs incurred and also the speed and accuracy of data collection (Fleming and Bowden, 2009). Data can also be collected continuously regardless of date or time and also without geographical limitation (Madge, 2006). Alternative sampling approaches have their own shortcomings. With only 7-8\% of the adult population in Ireland engaging in any type of recreational angling, and an even lower incidence of anglers targeting pike or trout, the alternative of random surveys of the general population is not economically practical for in-depth surveys of anglers' preferences. Intercept surveys at angling locations are no less expensive, are not immune from the same sampling biases, and additionally may be subject to biases associated with the frequency of angling at the intercept survey sites.

\subsection{Questionnaire Design}

The survey was conducted on-line with an invitation to participate sent to the selected anglers' email addresses. The questionnaire comprised four components. In the first part respondents were asked about their angling activities including locations, target species, frequency, and details about their expenditures on angling. The second and third parts were choice experiments, one each for trout and pike anglers, though each survey respondent only answered one set of choice experiment questions depending on their response to a prior question about whether they were most likely to fish for pike or brown trout.

Development of the choice experiment began with two focus groups comprising pike and brown trout anglers at both sessions, each lasting approximately 90 minutes. The focus groups entailed a structured discussion to elicit the issues of most concern to anglers, including ranking of importance, as well as an understanding of the issues within each topic. Through these discussions the six attributes of most importance were selected for inclusion in the choice experiments. A price or cost attribute was not included as it raised a particularly divisive discussion during the focus groups, including the opinion that any fees paid by anglers would not be reflected in additional 'on-the-ground' fishery management initiatives.

Each choice attribute had between three and six levels that were systematically varied to allow estimation of preferences for varying conditions, as outlined in Table 1 . The attributes specifically related to angling activity such as 
average catch, fish length, and bag limits are relatively straight-forward and one would anticipate that all positively impact on angler utility, possibly with the exception of the trout bag limit, as some anglers may feel that high bag limits threaten the sustainability of the fishery and their future utility. Lagarosiphon major (curly-leaved waterweed) is a high impact invasive species first recorded in Ireland in 2005. Lagarsiphon rapidly produces a large biomass and competitively excludes native aquatic macrophyte species and communities as well as altering habitat conditions for macroinvertebrate and fish communities (Caffrey et al., 2011). It also physically impedes boating and fishing activity. In addition to pike stock control, the management of this invasive species was the issue of most concern to anglers in the focus group discussions. Anglers also expressed strong concerns about water pollution, including the impact of pollution on visibility through the water column (especially so in the case of trout anglers) compared to the historical experience of anglers. Although visibility through the water column is not necessarily a measure of water quality, anglers clearly associated the two in the focus group discussions.

Pike stocks are routinely controlled at several Irish lakes. The choice experiment presented three control options: electro-fishing only, electro-fishing and gill-netting, and the cessation of pike stock controls. Electro-fishing is a scientific survey method used to sample fish populations to determine abundance, density, and species composition. Practitioners can release non-target species such as salmon and trout unharmed. Pike within the target size limit can then be removed to another water body. Electro-fishing is ineffective in deep water, as the electric current cannot penetrate the water column. Gill-netting is used to target pike in deep waters. Gill-netting can also involve killing non-target species, such as trout and salmon. However, such by-catch can be minimised by restricting gill-netting to areas predominantly inhabited by pike.

Table 1: Attributes and levels used in the choice experiments to assess the anglers' preferences for pike stock management

\begin{tabular}{|l|l|l|}
\hline Attribute & Description & Levels \\
\hline Catch & $\begin{array}{l}\text { Average number of pike/trout caught by } \\
\text { the average angler per day }\end{array}$ & $1,2,3$ (status quo), 4, 5 fish per day \\
\hline Length & $\begin{array}{l}\text { The average length of rod-caught pike at } \\
\text { the fishery (pike CE only) }\end{array}$ & $\begin{array}{l}55 \mathrm{~cm}, 70 \mathrm{~cm} \text { (status quo), } 85 \mathrm{~cm}, 100 \\
\mathrm{~cm}, 110 \mathrm{~cm}\end{array}$ \\
\hline Bag limit & $\begin{array}{l}\text { The number of trout an angler is permit- } \\
\text { ted to harvest in the course of a day's fish- } \\
\text { ing (trout CE only) }\end{array}$ & $\begin{array}{l}\text { Catch \& Release obligatory, 1, 2, 3, 4 } \\
\text { (status quo), 6 fish per day }\end{array}$ \\
\hline Pike stock control & $\begin{array}{l}\text { Pike control method including whether to } \\
\text { cease controls }\end{array}$ & $\begin{array}{l}\text { Cease culling, electro-fishing only, } \\
\text { electro-fishing \& gill-netting (status quo) }\end{array}$ \\
\hline $\begin{array}{l}\text { Invasive weed manage- } \\
\text { ment }\end{array}$ & $\begin{array}{l}\text { Annual change in Lagarosiphon cover as } \\
\text { compared to the previous fishing season }\end{array}$ & $\begin{array}{l}\text { Complete removal, -50\%, -20\%, No } \\
\text { change, +20\% (status quo) }\end{array}$ \\
\hline Water visibility & $\begin{array}{l}\text { The distance the angler can see into the } \\
\text { water column }\end{array}$ & \begin{tabular}{l}
1.5 metres (status quo), 2.5m, 3.5m, 5m \\
\hline
\end{tabular} \\
\hline
\end{tabular}

The attributes and their levels, as outlined in Table 1, were carefully explained to respondents in advance of any choice decision questions and included a visual image to demonstrate the extent of lagarosiphon growth. Respondents were also informed that all other unmentioned management measures remain unchanged across the scenarios being presented. In the survey each respondent was faced with 12 choice tasks, each consisting of 3 scenarios; a status quo scenario and two alternatives. The 'length' attribute was only included in the CE for pike anglers, whereas the 'bag limit' attribute was only included in the trout angler CE. The combinations of attribute levels presented in the 12 choice tasks were selected in a Bayesian efficient way, i.e., to minimize the determinant of the asymptotic variance-covariance matrix of the parameters (D-error) given the priors on the parameters, which were derived from a pilot survey comprising 26 respondents (Ferrini and Scarpa, 2007; Scarpa and Rose, 2008).

A total of 565 anglers were invited by email to participate in the survey in October 2016. Responses were received from 380 anglers, equivalent to a response rate of $67 \%$. Within the questionnaire there were item non-responses, including the CE component. A total of 144 respondents completed the CE for pike anglers and 197 respondents com- 
pleted the CE for trout anglers. In total we have data on 1597 choice occasions from the pike CE and a further 2253 choice occasions from the trout CE.

Table 2: Descriptive Statistics: Angler characteristics

\begin{tabular}{|c|c|c|c|c|c|c|c|c|}
\hline & \multicolumn{4}{|c|}{ Trout CE } & \multicolumn{4}{|c|}{ Pike CE } \\
\hline & \multicolumn{3}{|c|}{ Std. } & \multirow[b]{2}{*}{ Min } & \multicolumn{3}{|c|}{ Std. } & \multirow[b]{2}{*}{ Min } \\
\hline & Mean & Dev. & Max & & Mean & Dev. & Max & \\
\hline Fished in a lake in past 12 months & 0.81 & 0.40 & 1.00 & 0.00 & 0.90 & 0.30 & 1.00 & 0.00 \\
\hline $\begin{array}{l}\text { Fished designated brown trout lake } \\
\text { (with pike stock management) }\end{array}$ & 0.68 & 0.47 & 1.00 & 0.00 & 0.40 & 0.49 & 1.00 & 0.00 \\
\hline Angling frequency in last year (days) & 50.81 & 44.37 & 330 & 0.00 & 48.88 & 41.50 & 200 & 0.00 \\
\hline \multicolumn{9}{|l|}{ Angler self-assessed skill level: } \\
\hline Novice & 0.03 & 0.16 & 1.00 & 0.00 & 0.01 & 0.08 & 1.00 & 0.00 \\
\hline Average & 0.26 & 0.44 & 1.00 & 0.00 & 0.26 & 0.44 & 1.00 & 0.00 \\
\hline Above-average & 0.38 & 0.49 & 1.00 & 0.00 & 0.42 & 0.50 & 1.00 & 0.00 \\
\hline Advanced & 0.33 & 0.47 & 1.00 & 0.00 & 0.31 & 0.47 & 1.00 & 0.00 \\
\hline \multicolumn{9}{|l|}{ Angler age: } \\
\hline $15-34$ & 0.09 & 0.29 & 1.00 & 0.00 & 0.19 & 0.40 & 1.00 & 0.00 \\
\hline $35-44$ & 0.22 & 0.41 & 1.00 & 0.00 & 0.31 & 0.46 & 1.00 & 0.00 \\
\hline $45-65$ & 0.47 & 0.50 & 1.00 & 0.00 & 0.35 & 0.48 & 1.00 & 0.00 \\
\hline $66+$ & 0.12 & 0.32 & 1.00 & 0.00 & 0.01 & 0.12 & 1.00 & 0.00 \\
\hline Also a pike angler & 0.37 & 0.48 & 1.00 & 0.00 & & & & \\
\hline Also a trout angler & & & & & 0.38 & 0.49 & 1.00 & 0.00 \\
\hline Typically keep (i.e. harvest) fish caught: & & & & & & & & \\
\hline $\begin{array}{l}\text { "No" } \\
\text { "Yes-most of the time" or "Yes-Always" }\end{array}$ & $\begin{array}{l}0.26 \\
0.12\end{array}$ & $\begin{array}{l}0.44 \\
0.32\end{array}$ & $\begin{array}{l}1.00 \\
1.00\end{array}$ & $\begin{array}{l}0.00 \\
0.00\end{array}$ & $\begin{array}{l}0.73 \\
0.01\end{array}$ & $\begin{array}{l}0.45 \\
0.08\end{array}$ & $\begin{array}{l}1.00 \\
1.00\end{array}$ & $\begin{array}{l}0.00 \\
0.00\end{array}$ \\
\hline Number of respondents & & 19 & & & & 14 & & \\
\hline
\end{tabular}

\section{Results}

\subsection{Angler characteristics}

Table 2 outlines some characteristics of the survey respondents. In several areas the profile of pike and trout anglers are similar. For example, there are similar proportions of anglers that categorise themselves as being a novice or having 'average', 'above-average', or 'advanced' skill levels. Their levels of angling activity over the past year was also similar. Mean days fished in the past 12 months were 50.8 and 48.9 days with similar standard deviations. About $9 \%$ fished on average twice per week, $33 \%$ fished on average less than once every two weeks (i.e. up to 26 times in the year), and the balance fishing somewhere in between. While the analysis here distinguishes between being a pike or a trout angler, a substantial proportion of anglers target both species. Of survey respondents that typically target trout (and completed the trout CE) 37\% indicated that they have also fished for pike in past 12 months, and conversely $38 \%$ in the case of pike anglers. There were also differences in the angler profiles. The age profile of pike and trout anglers differs somewhat, with pike anglers having proportionally more anglers in the 15-44 age cohorts, with proportionally fewer in older age cohorts, especially those aged 66 and above. 
Table 3: Typical fishing trip, length and expenditure

\begin{tabular}{|c|c|c|c|c|c|c|}
\hline & $\mathrm{N}$ & Mean & Median & Std. Dev & Min & Max \\
\hline \multicolumn{7}{|c|}{ Length of typical fishing trip (days) } \\
\hline Trout anglers & 196 & 2.6 & 2.0 & 1.9 & 0.50 & $\geq 8$ \\
\hline Pike anglers & 143 & 2.7 & 2.0 & 1.9 & 0.50 & $\geq 8$ \\
\hline \multicolumn{7}{|c|}{ Expenditure on typical fishing trip, $€$} \\
\hline Trout anglers & 187 & 289 & 105 & 449 & 5 & 3,874 \\
\hline Pike anglers & 141 & 237 & 100 & 476 & 13 & 4,050 \\
\hline
\end{tabular}

Anglers fishing lake with pike stock management (past 12 months), €typical trip

$\begin{array}{lrrrrrr}\text { Yes (trout angler) } & 130 & 305 & 125 & 478 & 5 & 3,874 \\ \text { Yes (pike angler) } & 56 & 373 & 128 & 691 & 15 & 4,050 \\ \text { No (trout angler) } & 57 & 250 & 60 & 376 & 6 & 1,650 \\ \text { No (pike angler) } & 85 & 146 & 85 & 212 & 13 & 1,500\end{array}$

Typical trip expenditure by frequency of angling (past 12 months), $€$

\begin{tabular}{lrrrrrr}
$103+$ days (trout angler) & 18 & 280 & 133 & 314 & 10 & 1,050 \\
$103+$ days (pike angler) & 13 & 242 & 140 & 400 & 20 & 1,500 \\
$27-102$ days (trout angler) & 107 & 302 & 110 & 488 & 5 & 3,874 \\
$27-102$ days (pike angler) & 81 & 230 & 100 & 519 & 15 & 4,050 \\
0-26 days (trout angler) & 62 & 268 & 90 & 415 & 6 & 2,500 \\
0-26 days (pike angler) & 47 & 246 & 105 & 425 & 13 & 1,987 \\
\hline
\end{tabular}

Between $80-90 \%$ of anglers in the survey fished at lake sites in the past 12 months. Pike stock management occurs at 7 lake sites and just $40 \%$ of pike anglers fished in any of those lakes, whereas $68 \%$ of trout anglers did so. This suggests that pike anglers are more likely to avoid those specific sites. There are also substantial differences between anglers in relation to catch \& release activity. Approximately one quarter of trout anglers stated that they never harvest a caught fish, compared to almost three quarters of pike anglers. Just $1 \%$ of pike anglers typically keep the fish they catch most or all of the time, whereas $12 \%$ of trout anglers do.

The survey also asked a number of questions on angling related expenditure, both over the past 12 months and during a typical fishing trip across six categories of expenditure including travel expenses, fees/permits/guides, fishing tackle, food, accommodation and other expenses. In terms of annual expenditures the means are broadly similar for pike and trout anglers in the $€ 3,500-3,900$ range, though there are large standard deviations. These annual figures include expenditures on both domestic and foreign angling trips, as well as equipment such as boats. Table 3 presents expenditure during a typical trip by angling frequency and location for both pike and trout anglers. Mean expenditure by anglers on their most regular or typical fishing trips is $€ 289$ for trout anglers and $€ 237$ for pike anglers and comprises expenditures on food, accommodation, tackle (bait, lines, etc.), fees, permits, guides, as well as any travel expenses. Median values are approximately $€ 100$ in both cases. Median and mean lengths of trout and pike anglers' typical trips are also similar. These mean values for 'typical' trip expenditures are 40-60\% lower than a 2012 on-site survey of anglers at 50 prime angling locations across Ireland, which also included brown trout and pike anglers (TDI, 2013). In addition to different sampling approaches that may partially explain the differences, the two studies collect different expenditure information. The current study asked anglers about expenditures on a typical or regular fishing trip, whereas the TDI study collected information on the intercepted trip but such trips might not necessarily be representative of 'typical' trips. There is no substantial difference in mean trip expenditure of frequent or occasional anglers compared to the respective means of all pike or trout anglers. However, anglers, both trout and pike, who fish in designated brown trout fisheries that have pike stock management spend considerably more than their peers that fish elsewhere. 


\subsection{Preferred model}

The dependent variable in all the models estimated, the site choice decision, takes a value of 1 for the site scenario selected (from a choice of 3 options, a status quo scenario or two alternatives) and zero otherwise. As explanatory variables for the choice probabilities we used the following site attributes: average catch, bag limit (if applicable), average length (if applicable), pike stock control methods including no stock control, lagarosiphon cover, and water visibility. We also included an alternate specific constant for the status quo scenario, which is labelled as $A S C_{S Q}$. We interacted a number of angler characteristics with $A S C_{S Q}$, such as angling club membership, whether the angler fished in a lake with pike stock management and a number of socio-demographic variables, but the model results are not substantially different that those presented here. The models are estimated from an unbalanced panel of choice decisions, with a total of 2,253 and 1,597 choice observations for the trout and pike choice experiments respectively.

The results for the conditional logit model are reported in Table 4. The signs of the estimated coefficients are largely as anticipated in both models, with higher catch rates, greater in-water visibility and less lagarosiphon cover providing a positive inducement to anglers. Pike anglers additionally favour fish of greater length, though trout anglers appear not to have any strong preference on bag limits. As anticipated, the coefficient on gill-netting as a pike stock management option (i.e. the status quo) is strongly negative for pike anglers. The negative sign on the Gill variable in the trout model was unexpected, especially in light of the vocal support for gill-netting by trout anglers including during our focus group meetings. These results can be contrasted with those from the latent class model, which show much more diversity in preferences among both pike and trout anglers.

Model performance statistics such as the log likelihood, Akaike Information Criterion (AIC) and Bayes Information Criterion (BIC) were used for selecting the number of classes in the LCM model and are reported in Table 5. Three latent classes were selected as the preferred model for both trout and pike model estimations. In the case of trout a four latent class model did not estimate and the statistics suggest a better fit with three rather than two classes. In the case of the pike model based on log likelihood and AIC statistics 4 classes is potentially optimum. Though, the 4 class model is only 0.015 times as probable as the 3 class model based on the difference in AIC values. In one of the latent classes for the 4 class model only one explanatory variable had statistical significance, which limits its practical usefulness in understanding angler preferences. The BIC favours a 3 class model. The preferred model estimates are reported in Table 6.

Table 4: Site Choice Estimation - Conditional Logit Model Estimates

\begin{tabular}{|c|c|c|c|c|}
\hline & \multicolumn{2}{|c|}{ Trout } & \multicolumn{2}{|c|}{ Pike } \\
\hline & Estimate & Std. Error & Estimate & Std. Error \\
\hline Catch & $0.115 * * *$ & 0.025 & $0.127 * * *$ & 0.034 \\
\hline Bag & -0.045 & 0.036 & & \\
\hline Length & & & $0.021 * * *$ & 0.005 \\
\hline Electro & 0.039 & 0.122 & $-1.383 * * *$ & 0.142 \\
\hline Gill & $-0.358 * * *$ & 0.111 & $-3.271 * * *$ & 0.158 \\
\hline Weed & $-0.007 * * *$ & 0.001 & $-0.005 * * *$ & 0.001 \\
\hline Visibility & $0.089 * * *$ & 0.023 & 0.053 & 0.035 \\
\hline$A S C_{S Q}$ & $-0.270 *$ & 0.160 & -0.083 & 0.210 \\
\hline No. of anglers & \multicolumn{2}{|c|}{197} & \multicolumn{2}{|c|}{144} \\
\hline Observations & \multicolumn{2}{|c|}{2253} & \multicolumn{2}{|c|}{1597} \\
\hline Log likelihood & \multicolumn{2}{|c|}{-2180} & \multicolumn{2}{|c|}{-810} \\
\hline AIC & \multicolumn{2}{|c|}{4375} & \multicolumn{2}{|c|}{1633} \\
\hline $\mathrm{BIC}$ & \multicolumn{2}{|c|}{4415} & \multicolumn{2}{|c|}{1671} \\
\hline
\end{tabular}


Table 5: Criteria to select number of classes in latent class models

\begin{tabular}{|c|c|c|c|c|c|c|c|}
\hline & \multicolumn{3}{|c|}{ Trout $^{1}$} & \multicolumn{4}{|c|}{ Pike } \\
\hline Latent classes & 1 & 2 & 3 & 1 & 2 & 3 & 4 \\
\hline Parameters & 7 & 15 & 23 & 7 & 15 & 23 & 31 \\
\hline Log Likelihood & -2180.3 & -1895.1 & -1819.4 & -809.7 & -706.3 & -651.0 & -638.9 \\
\hline $\mathrm{AIC}$ & 4374.5 & 3820.1 & 3684.8 & 1633.4 & 1442.6 & 1348.1 & 1339.7 \\
\hline $\mathrm{BIC}$ & 4414.6 & 3905.9 & 3816.4 & 1671.0 & 1523.2 & 1471.7 & 1506.4 \\
\hline
\end{tabular}

${ }^{1}$ Model estimates did not converge for 4 latent trout angler classes

\subsection{Class membership probabilities}

By definition with LCM models we cannot describe the composition of the individual classes in terms of angler characteristics. However, by specifying membership probability as a function of socio-demographic variables we can say that the probability of membership varies depending on particular angler attributes. This approach usually gives some insight on the membership of the estimated latent classes. The LCM models are estimated with class membership probabilities specified a function of socio-demographic variables $\pi_{c}=g\left(\gamma_{c} z\right)$, as outlined in section 2.1. An extensive list of variables were included in $z$ during estimation, with variables covering standard socio-demographic characteristics (e.g. age, gender, education, occupation, location, income) as well as variables describing anglers' fishing activities (e.g. angling club membership, declared skill level, angling frequency, and whether they fished in lakes where pike stock management is undertaken). The estimates of the $\gamma_{c}$ parameters are almost universally statistically insignificant both in the trout and pike LCM models. This indicates is that the probability that an angler is a member of any of the three latent classes is not associated with any of these angler attributes. Class membership is not driven by factors that we would normally use to draw survey samples (e.g. age, education, location) or fishing related attributes (e.g. angling club member, skill level, angling frequency, etc.). Consequently, we cannot say anything about the likely composition of the latent classes, except that the probability of membership is not associated with any of the usual attributes that one might categorise anglers. We can surmise that class membership is related to anglers' philosophical, ecological or political beliefs related to fishing or fishery management.

We proceed for the remainder of the paper with latent class membership probability specified $\pi_{c}=f\left(\theta_{c}\right)$, as fully outlined in section 2.1. The estimated membership probabilities, $\hat{\pi}_{c}$, for the three classes of trout anglers are $0.61,0.26$ and 0.13 . The differences between classes is most obvious with respect to preferences for pike management controls and less so with respect to the other fishery attributes (i.e. catch, invasive weed etc.). The greater proportion (i.e. 61\%) of trout anglers are negatively disposed towards gill-netting (coefficient on Gill=-1.107), 26\% are moderately positively disposed (coefficient=0.492) and $13 \%$ of trout anglers are more strongly in favour of gill-netting (coefficient=1.19). Preferences towards electro-fishing only are less clear-cut, as the coefficient on Electro is statistically significant for only one of the latent classes.

The membership probabilities for the three pike angler latent classes are 0.26, 0.69 and 0.05 . Similar to trout anglers, preferences differ across the classes for a range of fishery attributes. For example, the average number of fish caught is not an important attribute for latent class 3, the smallest of the three classes. However, all three classes are negatively disposed towards pike stock management. Latent class 2, the largest group at 69\%, are the most strongly opposed to both gill-netting and electro-fishing. While all three classes are negatively disposed towards electro-fishing (i.e. negative coefficient), the Electro coefficient is not statistically significant for latent class 1.

\subsection{Marginal rates of substitution}

Usually MRS is calculated between a non-monetary and a monetary attribute and expressed as marginal willingness to pay (WTP). As noted earlier, a price or cost attribute was not included in the survey because it was too divisive. For our purposes we express MRS in terms of metres of water visibility. The choice of in-water visibility is arbitrary but is an easily comprehended metric to consider anglers' preferences with respect to the other fishery attributes. MRS calculations are reported in Table 7 and interpreted as follows. For a bag limit of one additional fish a trout angler in 


\begin{tabular}{|c|c|c|c|c|c|c|c|}
\hline & & Trout CE & & & & Pike CE & \\
\hline \multirow{3}{*}{ Catch } & $c=1$ & $c=2$ & $c=3$ & & $c=1$ & $c=2$ & $c=3$ \\
\hline & $0.173 * * *$ & -0.039 & $0.315 * * *$ & Catch & $0.254 * * *$ & $0.565 * * *$ & -0.067 \\
\hline & $(0.031)$ & $(0.051)$ & $(0.092)$ & & $(0.068)$ & $(0.175)$ & $(0.153)$ \\
\hline \multirow[t]{2}{*}{ Bag } & -0.025 & $-0.299 * * *$ & $0.324 * * *$ & Length & $0.035 * * *$ & $0.058 * * *$ & -0.008 \\
\hline & $(0.064)$ & $(0.083)$ & $(0.088)$ & & $(0.01)$ & $(0.016)$ & $(0.021)$ \\
\hline \multirow[t]{2}{*}{ Electro } & -0.262 & $0.702 * *$ & 0.444 & Electro & -0.381 & $-4.378 * * *$ & $-1.917 * *$ \\
\hline & $(0.163)$ & $(0.325)$ & $(0.932)$ & & $(0.282)$ & $(0.978)$ & $(0.854)$ \\
\hline \multirow[t]{2}{*}{ Gill } & $-1.107 * * *$ & $0.492 *$ & $1.19 * *$ & Gill & $-1.686 * * *$ & $-12.659 * * *$ & $-3.217 * * *$ \\
\hline & $(0.263)$ & $(0.26)$ & $(0.932)$ & & $(0.313)$ & (2.778) & $(0.837)$ \\
\hline \multirow[t]{2}{*}{ Weed } & $-0.011 * * *$ & -0.003 & $-0.012 * * *$ & Weed & $-0.006^{* * *}$ & $0.026^{* *}$ & $-0.007 * * *$ \\
\hline & $(0.002)$ & $(0.002)$ & $(0.003)$ & & $(0.002)$ & $(0.011)$ & $(0.002)$ \\
\hline \multirow[t]{2}{*}{ Visibility } & $0.096 * * *$ & $0.125 * * *$ & $0.307 * * *$ & Visibility & $0.083^{* *}$ & $0.92 * * *$ & $-0.277 * * *$ \\
\hline & $(0.024)$ & $(0.045)$ & $(0.092)$ & & $(0.037)$ & $(0.326)$ & $(0.063)$ \\
\hline \multirow[t]{2}{*}{$A S C_{S Q}$} & $-1.898 * * *$ & -0.207 & $1.986 * * *$ & $A S C_{S Q}$ & $-1.545^{* * *}$ & $4.134 * *$ & $2.487 * *$ \\
\hline & $(0.31)$ & $(0.288)$ & $(0.505)$ & & $(0.562)$ & $(1.86)$ & $(0.969)$ \\
\hline \multirow[t]{2}{*}{$\pi_{c}$} & $0.613 * * *$ & $0.26 * * *$ & $0.127 * * *$ & $\pi_{c}$ & $0.257 * * *$ & $0.694 * * *$ & $0.05 * *$ \\
\hline & $(0.054)$ & $(0.052)$ & $(0.024)$ & & $(0.04)$ & $(0.041)$ & $(0.02)$ \\
\hline $\mathrm{N}$ & & 197 & & $\mathrm{~N}$ & & 144 & \\
\hline Obs & & 2253 & & Obs & & 1597 & \\
\hline Log likelihood & & -1819 & & Log likelihood & & -651 & \\
\hline AIC & & 3685 & & AIC & & 1348 & \\
\hline
\end{tabular}

Standard errors in parentheses, * $p<0.10, * * p<0.05$, *** $p<0.01$ 
latent group $c=3$ is willing to substitute 1.05 metres of water visibility. Latent groups 2 and 3 are willing to substitute water visibility in favour of pike population control, either via electro fishing or gill-netting. In the case of latent group 3, they would substitute almost 3.87 metres of water visibility in favour of gill-netting. Latent group 1 derive dis-utility from pike stock control but have much stronger preferences. They would require 11.55 metres more, rather than less, water visibility to select fishing sites with gill-netting stock control. Irrespective of whether trout anglers favour pike stock control or not, it dominates preferences. MRS for other fishery attributes are all substantially smaller in magnitude.

Unsurprisingly pike stock control also dominates pike anglers' preferences. Latent groups 1 and 2 would select sites with gill-netting only if they had very high levels of water visibility. Group 3, which is the smallest of the 3 latent pike groups, at 5\% probability, derive dis-utility from water visibility as indicated by the negative parameter estimate, -0.277 , in Table 6. But similar to their peers in latent classes 1 and 2, they have strong preferences on the gill-netting attribute, willing to substitute over 11.6 metres of water visibility. Where pike control is implemented via electro fishing, preferences have less intensity compared to those for gill-netting across the three pike angler groups, with the exception of latent class 1 who are indifferent to electro-fishing.

Compared to all angler groups, pike anglers in latent class 1 have the strongest preferences with respect to the catch rate. They are willing to substitute over 3 metres of visibility if a site had a catch rate one fish higher, on average. This is substantially higher than any of the other latent groups, some of which do not have a statistically significant MRS with respect to catch rate.

After pike stock control, the control of invasive weeds (i.e. lagarosiphon) was the topic that most dominated the survey focus group discussions. There was a voiced fear that the unimpeded spread of lagarosiphon would substantially disrupt anglers' recreational activity. Its MRS is relatively low compared to other fishery attributes.

\subsection{Odds ratios}

Calculated odds ratios are reported in Table 8. At the top of the table we compare the status quo scenario, which is described in the first column, with a scenario where the average catch rate is 4 fish, one more than the status quo. The odds that a trout angler in latent class 1 would select the scenario option with the higher average catch rate is 1.2. Pike anglers in latent class 2 have stronger preferences for higher catches with an odds ratio of 1.8. Across the latent classes, pike anglers are more responsive to catch rates with an odds ratio of 1.6 compared to 1.1 for trout anglers.

About one-eight of trout anglers (i.e. latent class 3) are negatively disposed to reducing the daily bag limit and are only 0.7 times as likely to fish at a site with bag limit one trout less. Most trout anglers are not averse to a reduction in the daily bag limit to three trout, one less than the status quo. Overall the odds ratio for a site with a lower bag limit is 1.1 , though it is not statistically different than 1. Pike anglers are 1.6 times more likely to select a fishing site where the average length of pike caught is $10 \mathrm{~cm}$ more than the status quo, though this is driven by latent classes 1 and 2 that have strong preferences for larger fish.

Two alternative pike control scenarios (no control, or electro-fishing only) are compared with the status quo option, which is electro-fishing and gill-netting. From the coefficient estimates in Table 6 we know that all pike anglers are negatively disposed to all methods of pike stock control, as there are negative coefficients on the Electro and Gill variables in each latent class. The odds ratios that pike anglers would choose a site with reduced or no pike stock control are high, thought not all are significantly different than one. This reflects the relatively high standard error (s.e.) on the probability estimate for selecting the status quo option for anglers in latent classes 2 and 3. For example, the probability that a latent class 3 pike angler selects the status quo is 0.04 (s.e. 0.03 ), compared to 0.96 (s.e. 0.03 ) for the no pike control option. The odds ratio of 24.9 for the no pike control option consequently has a large standard error estimate of 20.88, which results in it being insignificantly different than 1. Overall, pike anglers are 14 times more likely to select a site with electro fishing only, or nearly 23 times more likely to select a site with no pike control, both compared to the status quo of both electro-fishing and gill-netting pike control. 
As we saw when examining the estimates of marginal rates substitution, trout anglers' preferences for pike control are more nuanced. Across the latent classes in the LCM model the coefficient estimates on the Gill variable had both positive and negative signs and the Electro variable was significant in one case only. The largest latent class $(61 \%)$ is 3 times more likely to choose a site that has no pike control compared to the status quo. In contrast the smallest latent class (13\%) is only 0.3 times as likely to choose a site with no pike control compared to the status quo (i.e. gill-netting). Latent class 2, which comprises approximately a quarter of the trout sample, are 0.6 times as likely to choose a site without pike stock control compared to the status quo. Faced with a choice between the status quo and electro-fishing only as pike control methods, trout anglers as a whole are 1.6 times more likely to select the site with electro-fishing only. When the choice is between the status quo and no pike control trout anglers are 1.4 times more likely to select the site with no pike control.

Trout anglers are substantially more concerned about the growth of lagarosiphon than pike anglers, which mirrors the focus group discussions. The status quo scenario assumes a $20 \%$ growth in lagarosiphon without any management intervention. The scenario examined in Table 8 considers a $20 \%$ reduction in lagarosiphon compared to the previous year. Trout anglers are 1.4 times more likely to select a site with that level of lagarosiphon control compared to the status quo, whereas pike anglers are only 0.5 times as likely to choose such an option.

Pollution and water quality was a prominent issue in the focus groups, especially among trout anglers. Based on the model estimates pike anglers are equally if not more concerned. Almost the entire samples of pike and trout anglers favour sites with greater in-water visibility, with trout anglers 1.2 times and pike anglers over 2.5 times as likely to visit sites with double the visibility compared to the status quo (i.e. 3 versus 1.5 metres).

We also examine in Table 8 odds ratios for a suite of potential policy options. For example, no pike control with a substantial reduction in lagarosiphon, or additionally changes in the bag limit, water visibility, etc.. Pike anglers are strongly adverse to sites with any form of pike control and regardless of other site attributes have high odds ratios of not selecting the status quo. Trout anglers are more likely to substitute between site attributes. If no pike stock control is combined with a change in lagarosiphon coverage from $+20 \%$ to $-20 \%$, the odds that trout anglers select the scenario option increases from 1.4 to 1.9 compared to the status quo. Furthermore, if the daily bag limit is reduced by half to two fish (for sustainability reasons) and coincidently if in-water visibility increases by 1 metre, the odds ratio increases to 2.4. In summary, if changes in pike control are combined with changes in other fishery attributes, such as bag limits, invasive weed coverage, or water quality/clarity, the odds that trout anglers would support such a measure is likely to increase substantially.

Table 7: Marginal rates of substitution between attributes

\begin{tabular}{|c|c|c|c|c|c|c|c|}
\hline & \multicolumn{3}{|c|}{ Trout CE } & & \multicolumn{3}{|c|}{ Pike CE } \\
\hline \multirow{3}{*}{ Catch } & $c=1$ & $c=2$ & $c=3$ & & $c=1$ & $c=2$ & $c=3$ \\
\hline & $-1.81 * * *$ & 0.31 & $-1.03 * * *$ & Catch & $-3.06 * *$ & $-0.61 * * *$ & -0.24 \\
\hline & $(0.61)$ & $(0.44)$ & $(0.35)$ & & (1.38) & $(0.08)$ & $(0.52)$ \\
\hline \multirow[t]{2}{*}{ Bag } & 0.26 & $2.4 * *$ & $-1.05 * *$ & Length & $-0.43 * *$ & $-0.06 * * *$ & -0.03 \\
\hline & $(0.64)$ & (1.07) & $(0.42)$ & & $(0.2)$ & $(0.01)$ & (0.07) \\
\hline \multirow[t]{2}{*}{ Electro } & $2.74 *$ & $-5.64 *$ & -1.45 & Electro & 4.59 & $4.76 * * *$ & $-6.92 * *$ \\
\hline & (1.58) & (3.16) & (2.90) & & (4.06) & (1.22) & (3.35) \\
\hline \multirow[t]{2}{*}{ Gill } & $11.55^{* * *}$ & -3.95 & $-3.87 * *$ & Gill & $20.31 * *$ & $13.76 * * *$ & $-11.61 * *$ \\
\hline & (3.07) & (2.75) & (1.86) & & (9.64) & (3.05) & (4.62) \\
\hline \multirow[t]{2}{*}{ Weed } & $0.12 * * *$ & 0.03 & $0.04 * * *$ & Weed & $0.07 * *$ & $-0.03 * * *$ & $-0.03 * * *$ \\
\hline & (0.03) & $(0.02)$ & $(0.01)$ & & $(0.04)$ & $(0.00)$ & $(0.01)$ \\
\hline Visibility & - & - & - & Visibility & - & - & - \\
\hline$\pi_{c}$ & 0.61 & 0.26 & 0.13 & $\pi_{c}$ & 0.26 & 0.69 & 0.05 \\
\hline
\end{tabular}


Table 8: Odds ratios for various policy scenario options, $P($ Scenario option $) / P($ Status Quo)

\begin{tabular}{|c|c|c|c|c|}
\hline Status quo & Scenario & Latent Class & Trout CE & Pike CE \\
\hline \multirow{11}{*}{ Avg Catch $=3$ fish } & Avg Catch: & 1 & $1.2 * * *$ & $1.3^{* * * *}$ \\
\hline & 4 fish & 2 & 1.0 & $1.8^{* *}$ \\
\hline & & 3 & $1.4^{* * *}$ & 0.9 \\
\hline & & Total & $1.1 * * *$ & $1.6^{* * * *}$ \\
\hline & Trout: bag limit $=3$ & 1 & 1.0 & $1.4^{* * *}$ \\
\hline & or & 2 & $1.3 * * *$ & $1.8 * * *$ \\
\hline & Pike: length $80 \mathrm{~cm}$ & 3 & $0.7 * * *$ & 0.9 \\
\hline & & Total & 1.1 & $1.6^{* * * *}$ \\
\hline & Pike control: & 1 & $2.3^{* * *}$ & $3.7^{* * *}$ \\
\hline & Electro-fishing & 2 & 1.2 & 3947.6 \\
\hline & & 3 & 0.5 & 3.7 \\
\hline \multirow{3}{*}{$\begin{array}{l}\text { Bag limit }=4 \text { trout } \\
\text { (Trout } \mathrm{CE} \text { ) }\end{array}$} & & Total & $1.6^{* * *}$ & $14.3^{* * *}$ \\
\hline & Pike Control: & 1 & $3^{* *}$ & $5.4^{* * * *}$ \\
\hline & No control & 2 & $0.6^{* *}$ & 314524 \\
\hline \multirow{3}{*}{$\begin{array}{l}\text { Avg Length }=70 \mathrm{~cm} \\
\text { (Pike CE) }\end{array}$} & & 3 & $0.3^{* * *}$ & 24.9 \\
\hline & & Total & $1.4^{* *}$ & $22.8^{* * *}$ \\
\hline & Lagarosiphon: & 1 & $1.6^{* * *}$ & $1.3^{* * * *}$ \\
\hline \multirow{4}{*}{$\begin{array}{l}\text { Pike Stock control = } \\
\text { electro-fishing \& } \\
\text { gill netting }\end{array}$} & $-20 \%$ p.a. & 2 & 1.1 & $0.4^{* * *}$ \\
\hline & & 3 & $1.6^{* * *}$ & $1.3^{* * *}$ \\
\hline & & Total & $1.4 * * *$ & $0.5^{* * *}$ \\
\hline & In-water & 1 & $1.2 * * *$ & $1.1^{* *}$ \\
\hline \multirow[t]{2}{*}{ Lagarosiphon: $=+20 \%$} & visibility: $3 \mathrm{~m}$ & 2 & $1.2^{* *}$ & 4.0 \\
\hline & & 3 & $1.6^{* * *}$ & $0.7^{* * * *}$ \\
\hline \multirow[t]{9}{*}{ Water visibility $=1.5 \mathrm{~m}$} & & Total & $1.2 * * *$ & $2.5^{* *}$ \\
\hline & No pike control & 1 & $4.8^{* * *}$ & $6.9^{* * *}$ \\
\hline & \& lagarosiphon & 2 & 0.7 & 111648 \\
\hline & $-20 \%$ p.a. & 3 & $0.5^{* *}$ & 33.3 \\
\hline & & Total & $1.9^{* * *}$ & $28.4^{* * *}$ \\
\hline & No pike control \& & 1 & $5.5^{* *}$ & $5.3^{* * * *}$ \\
\hline & lagarosiphon $-20 \% \&$ & 2 & 1.4 & 156915 \\
\hline & visibility $2.5 \mathrm{~m} \&$ & 3 & $0.3 * * *$ & 27.4 \\
\hline & $\begin{array}{c}\text { Trout: bag limit }=2 \\
\text { OR Pike: length }=60 \mathrm{~cm}\end{array}$ & Total & $2.4 * * *$ & $22.4 * * *$ \\
\hline
\end{tabular}

\section{Discussion}

The objectives of this paper were to understand the preferences for stock management tools; identify the heterogeneity within anglers regarding preferences for pike stock management; and evaluate the impact of stock management decisions on angler activity. These objectives are interrelated but we consider each in turn.

\subsection{Preferences for stock management tools}

In addition to the pike stock management through electro-fishing and gill netting, fishery managers have several other mechanisms in which to affect fish stocks. For example, bag limits or measures to improve habitat can indirectly affect fish stocks. While it is recognised that anglers' preferences may be species specific (Arlinghaus et al., 2014), preferences can vary substantially across anglers even within one target species. Across the latent classes, either of pike or trout anglers, we find that preferences differ considerably for fishery attributes that managers may seek to regulate or adjust for the purpose of managing fish stocks, e.g. bag limits. First, taking daily bag limits, trout anglers' preferences differ substantially. The largest latent class group are indifferent to bag limits (i.e. coefficient estimate is statistically insignificant), whereas preferences of the other two latent classes are diametrically opposed. For a bag limit 1 trout higher, latent class 3 anglers would substitute 1 metre of water visibility, whereas latent class 2 anglers require 2.4 metres of additional water visibility. These results are consistent with a broad literature that finds that anglers' preferences are heterogeneous (e.g. Arlinghaus and Mehner, 2005; Connelly et al., 2001; Fisher, 1997; Hutt and Bettoli, 2007) but contrasts with studies that assume homogeneous preferences (e.g. Oh et al., 2005; Whitehead et al., 2011).

A number of previous papers have found that catch rates are both important and positively related to participation, for instance with higher licence sales being associated with higher catch rates (Dabrowska et al., 2014; Patterson 
and Sullivan, 2013; Loomis and Fix, 1998). However, Dabrowska et al. (2014) also note that catch is not the only or primary consideration with other factors such as accessibility or socio-demographic characteristics being important. The importance of catch rates is reflected in the models estimated here but catch is not of primary importance to all anglers. Latent class 2 trout anglers who favour lower bag limits are also indifferent to catch rates, which suggests that sustainability issues may underpin their preferences. This view is consistent with Arlinghaus and Mehner (2005) who suggest that personal beliefs and attitudes are important determinants of anglers' preferences for fishery management measures. Latent class 2 comprises approximately one-quarter of trout anglers, and their preferences on bag limits suggests that a substantial minority of anglers may be supportive of further bag limit controls to maintain the sustainability of fish stocks, which is similar to findings related to anglers views of rehabilitation of trout fisheries in Lake Huron (Hunt et al., 2014). There are similar results for pike anglers in latent class 3. With estimated parameters on both average catch and length statistically insignificant it suggests that some pike anglers have no preference for catching more and larger sized fish. This result appears peculiar but could be an artefact of sample size, as the composition of latent class 3 is quite small at $5 \%$ of a sample of 144 anglers. In general, where preferences are for higher average catches, the importance of catch varies substantially and is illustrated by the marginal rates of substitution reported in Table 7. For example, preferences for higher catch rates among pike anglers in latent class 1 is 5-times that of latent class 2 pike anglers, whereas for trout anglers in latent class 3 it is almost twice that of latent class 1 trout anglers.

Fish size is an important attribute for anglers (Adamowicz et al., 1994). Size was only considered in the pike CE and is an important attribute for two of the three latent classes. Indifference to size among latent class 3 pike anglers is surprising but as noted above this may reflect the small size of this group.

A considerable focus during the survey focus groups was a concern for the invasive aquatic species Lagarosiphon major. Lagarsiphon physically impedes boating and fishing activity, competitively excludes native aquatic macrophyte species, and alters habitat conditions for macroinvertebrate and fish communities (Caffrey et al., 2011). Trout anglers universally have preferences for its eradication, whereas there are mixed preferences among pike anglers. Pike anglers' preference in favour of lagarsiphon growth reflects the fact that it renders the habitat more suitable for pike (Caffrey et al., 2010, 2011). The magnitude of preferences for the control of lagarsiphon are relatively low compared to other fishery attributes, as reflected in the MRS values in Table 7. This does not mirror the scale and intensity of the two focus group discussions, which may either reflect the idiosyncratic nature of those particular discussions or alternatively the groups may not have well represented the 'silent majority' of anglers, echoing a point by Hunt et al. (2010) that the preferences of anglers who typically voice their perspectives may not be representative of all anglers.

\subsection{Preference heterogeneity for pike stock management}

What is clear from the model estimates is that anglers' preferences for pike stock control are more complex than the superficial story that trout anglers favour pike stock control and pike anglers oppose it. In our sample almost 2 in 5 pike anglers also fished for brown trout in the past twelve months, and similarly for trout anglers fishing for pike. These facts are reflected in the model estimates, which also suggest that there is no 'typical' pike or trout angler in respect of preferences towards pike stock control. This is at odds with a vociferous public campaign led by trout angling representative organisations arguing that all their membership favour pike stock control. The argument by Hunt et al. (2010) that the voices that fishery managers hear are not representative of 'silent majority' of anglers is clearly applicable in this instance also. No single voice truly represents all anglers. Even among pike anglers, where all are negatively disposed towards pike stock control measures, the weight of feeling towards stock control, compared to other fishery attributes, varies considerably.

Our assessment is that when faced with two similar fishing destinations, one in which pike stocks are managed by gill-netting (and electro-fishing) and a second where pike stocks are not actively managed, the probability that an angler, irrespective of targeting trout or pike, will choose the no pike control site is higher. We found no evidence that the heterogeneity of preferences for pike stock control, either among trout or pike anglers, is linked to particular socio-demographic or fishery specific variables (e.g. age, education, skill level, angling frequency, club membership). This suggests that preferences for pike stock control may be driven by underlying personal ethical beliefs on the (sustainable) management of natural resources. Arlinghaus and Mehner (2005) drew a similar conclusions finding 
that anglers' beliefs and attitudes, as well as their consumptive orientation were more meaningful predictors of fishery management strategies than typical angler variables such as demographics, angler experience or angler preferences.

\subsection{Impact of stock management on angler activity}

An important question that arises from analysis of this type is what are the likely impacts of a change in pike stock control measures? Prior to attempting to answer such a question it is important to acknowledge that while our sample does provide insights to anglers' potential responses, we cannot guarantee that the sample is fully representative of the populations of pike and trout anglers. As noted earlier, membership of the angler panel was widely advertised but without a register of anglers there is no means gauge the representativeness of the panel. Among surveyed pike and trout anglers, they were broadly similar in terms of angling frequency and self-assessed proficiency. Consequently, it is reasonable to say that the samples are of similarly committed pike and trout anglers and it is fair to compare preferences across these two samples.

Conditional on the data samples available it is possible to infer a number of things about the likely impacts of a change in pike stock control measures. In the first instance, if pike stock controls in designated brown trout fisheries either cease or are limited to electro-fishing only it is likely that the number of pike anglers frequenting such fisheries is likely to increase. All else equal, pike anglers (almost universally) would choose to fish at a site with lower levels of pike control, and especially so if pike controls cease altogether. The probability that trout anglers visit a site changes; some are more likely to visit, whereas others are less likely to visit. Unfortunately, we cannot estimate changes in numbers of angling trips by pike or trout anglers though we can conclude that the composition and frequency of anglers will change. With a different composition of anglers the economic impact, in terms of anglers' expenditures in the vicinity of the fishing site, could change. However, on a per-angler-trip basis any changes are likely to be negligible, as there is no substantial difference in either pike and trout anglers' expenditures from Table 3.

Thus far we have considered only first order impacts of any potential changes in pike stock management, i.e. the response of anglers to the management change. A change in pike control will have a direct impact on pike stocks and consequent impacts on aquatic ecosystems in general. Establishing what these impacts might be requires further research, though the impacts are unlikely to be negligible. For instance, a study of natural versus human-induced selection of pike stocks on Windermere lake in the UK found that natural selection consistently acted against small pike and human-induced selection consistently favoured small pike (Carlson et al., 2007). Additionally, ceasing stock management, which primarily targets older larger pike, may result in considerable benefits for the pike fishery both in terms of quality and its long-term conservation (Arlinghaus et al., 2010). Therefore, changes in pike population structure could mean significant changes in the attributes of both trout and pike fisheries, including attributes over which anglers have preferences. Some of these as yet unknown changes may be considered positively by anglers and lead to a higher probability of site selection (and consequently more angler visits). Equally, the opposite is also likely. Therefore, we have not been able to consider how anglers are likely to respond to any longer term impacts associated with a change in pike stock control.

\section{Conclusion}

This paper examines anglers' preferences for active stock management of pike populations within designated wild brown trout fisheries in Ireland. While the policy of pike control has a long history (IFI, 2014), it is not without controversy and conflict. Pike stocks are controlled with the objective of protecting trout stocks, and the naive assumption would be that trout anglers favour such management intervention. The reality is quite a different picture. The majority of trout anglers in our sample are opposed to pike stock control, and all else equal, are more likely to choose fishing sites where pike stocks are not actively managed. We cannot attest to why this is the case but may be partly explained by the fact that many trout anglers also fish for pike. Among the trout and pike anglers in our sample almost 2-in-5 anglers also fished for the other species. Other reasons why anglers oppose pike stock control may be related to anglers' philosophical or ecological views. Conversely there is a substantial minority (39\%) of trout anglers that could 
be considered advocates of pike control, with about one-third of these being more extreme in their preferences. Not surprisingly pike anglers do not support pike stock control.

Within the paper we consider pike and trout anglers as being distinct. The survey distinguished such anglers by asking respondents to specify the fishery in which they are most likely to fish. In reality many pike anglers also fish for trout and vice versa; approximately $37 \%$ in the surveyed anglers. It is therefore not surprising that there is such heterogeneity in anglers' preferences towards pike stock control. Even among pike anglers, all of whom experience dis-utility from pike stock control, preferences are quite heterogeneous with respect to pike stock control. The majority of pike anglers are strongly opposed to gill-netting, with smaller proportions of anglers having progressively more moderate, though negative, preferences towards gill-netting.

In terms of advocacy and angler representative groups we conclude that no single voice truly represents all anglers. In the context of the particular issue of pike stock control, we provide evidence that the vociferous campaign by trout angler representative bodies supporting the continuation of pike stock control may not reflect the majority of trout anglers who do not support pike stock control. We found no evidence that the heterogeneity of preferences for pike stock control, either among trout or pike anglers, is linked to particular socio-demographic or fishery specific variables (e.g. age, education, skill level, angling frequency, club membership). Instead we suggest that preferences may be driven by underlying personal beliefs and attitudes.

An important policy question arises is how anglers are likely to respond to any potential future changes in pike stock control measures? Unfortunately, we cannot estimate changes in numbers of angling trips though we can conclude that the composition and frequency of anglers visiting affected sites will change. On a per-angler-trip basis we conclude that the net economic impact in terms of angler expenditures is likely to be negligible.

The paper considers only first order effects of a management change towards pike stock control, essentially anglers preferences for the act of pike stock control. But changes in pike stock control are likely to have wider ecosystem impacts including on attributes of trout and pike fisheries over which anglers have preferences (e.g. catch rates, length, etc.). The nature of these ecosystem impacts are as of yet unknown and therefore it is not possible at this point to estimate the longer term response of anglers. Once information on the longer term biological impacts is available the current models can be used to assess anglers' responses in the longer term.

\section{Acknowledgements}

This research has been financially supported by Inland Fisheries Ireland. I wish to thank Stephen Hynes for useful suggestions and acknowledge Benjamin Breen for his assistance in the preparation for the choice experiment survey. 


\section{References}

Aas, Ø., Haider, W., and Hunt, L. (2000). Angler responses to potential harvest regulations in a Norwegian sport fishery: a conjoint-based choice modeling approach. North American Journal of Fisheries Management, 20(4):940-950.

Aas, Ø. and Kaltenborn, В. P. (1995). Consumptive orientation of anglers in Engerdal, Norway. Environmental Management, 19(5):751-761. https://doi.org/10.1007/BF02471957.

Adamowicz, W., Louviere, J., and Williams, M. (1994). Combining revealed and stated preference methods for valuing environmental amenities. Journal of environmental economics and management, 26(3):271-292. https://doi.org/10.1006/jeem.1994.1017.

Arlinghaus, R. (2004). A human dimensions approach towards sustainable recreational fisheries management. Turnshare Ltd., London.

Arlinghaus, R. (2005). A conceptual framework to identify and understand conflicts in recreational fisheries systems, with implications for sustainable management. Aquatic Resources, Culture and Development, 1(2):145-174. https://doi.org/10.1079/ARC200511.

Arlinghaus, R. (2006). Overcoming human obstacles to conservation of recreational fishery resources, with emphasis on Central Europe. Environmental Conservation, 33(01):46-59. https://doi.org/10.1017/S0376892906002700.

Arlinghaus, R., Alós, J., Beardmore, B., Daedlow, K., Dorow, M., Fujitani, M., Hühn, D., Haider, W., Hunt, L., Johnson, B., Johnston, F., Klefoth, T., Matsumura, S., Monk, C., Pagel, T., Post, J., Rapp, T., Riepe, C., Ward, H., and Wolter, C. (2017). Understanding and managing freshwater recreational fisheries as complex adaptive social-ecological systems. Reviews in Fisheries Science \& Aquaculture, $25(1): 1-41$. http://dx.doi.org/10.1080/23308249.2016.1209160.

Arlinghaus, R., Beardmore, B., Riepe, C., Meyerhoff, J., and Pagel, T. (2014). Species-specific preferences of German recreational anglers for freshwater fishing experiences, with emphasis on the intrinsic utilities of fish stocking and wild fishes. Journal of fish biology, 85(6):1843-1867. https://doi.org/10.1111/jfb.12546.

Arlinghaus, R., Matsumura, S., and Dieckmann, U. (2010). The conservation and fishery benefits of protecting large pike (Esox lucius 1.) by harvest regulations in recreational fishing. Biological Conservation, 143(6):1444-1459. https://doi.org/10.1016/j.biocon.2010.03.020.

Arlinghaus, R. and Mehner, T. (2005). Determinants of management preferences of recreational anglers in Germany: habitat management versus fish stocking. Limnologica-Ecology and Management of Inland Waters, 35(1):2-17. https://doi.org/10.1016/j.limno.2004.10.001.

Arlinghaus, R., Mehner, T., and Cowx, I. G. (2002). Reconciling traditional inland fisheries management and sustainability in industrialized countries, with emphasis on Europe. Fish and fisheries, 3(4):261-316. https://doi.org/10.1046/j.1467-2979.2002.00102.x.

Caffrey, J., Millane, M., Evers, S., and Moran, H. (2011). Management of Lagarosiphon major (Ridley) moss in Lough Corrib - a review. Biology and Environment: Proceedings of the Royal Irish Academy, 111B:205-212. https://doi.org/10.3318/BIOE.2011.16.

Caffrey, J. M., Millane, M., Evers, S., Moron, H., and Butler, M. (2010). A novel approach to aquatic weed control and habitat restoration using biodegradable jute matting. Aquatic Invasions, 5(2):123-129. https://doi.org/10.3391/ai.2010.5.2.01.

Carlson, S. M., Edeline, E., Asbjørn Vøllestad, L., Haugen, T., Winfield, I. J., Fletcher, J. M., Ben James, J., and Stenseth, N. C. (2007). Four decades of opposing natural and human-induced artificial selection acting on Windermere pike (Esox lucius). Ecology Letters, 10(6):512-521. https://doi.org/10.1111/j.1461-0248.2007.01046.x.

Champ, P. A. (2003). Collecting survey data for nonmarket valuation. In Champ, P. A., Boyle, K. J., and Brown, T. C., editors, A primer on nonmarket valuation, pages 59-98. Springer, Netherlands.

Charles, A. T., editor (2001). Sustainable Fishery Systems. Blackwell Science, Oxford, UK.

Churchill, T. N., Bettoli, P. W., Peterson, D. C., Reeves, W. C., and Hodge, B. (2002). Angler conflicts in fisheries management: a case study of the striped bass controversy at Norris Reservoir, Tennessee. Fisheries, 27(2):10-19. https://doi.org/10.1577/15488446(2002)027<0010:ACIFM>2.0.CO;2.

Connelly, N. A., Knuth, B. A., and Brown, T. L. (2001). An angler typology based on angler fishing preferences. Transactions of the American Fisheries Society, 130(1):130-137. https://doi.org/10.1577/1548-8659(2001)130<0130:AATBOA>2.0.CO;2.

Cowx, I., Arlinghaus, R., and Cooke, S. (2010). Harmonizing recreational fisheries and conservation objectives for aquatic biodiversity in inland waters. Journal of Fish Biology, 76(9):2194-2215. https://doi.org/10.1111/j.1095-8649.2010.02686.x.

Craig, J. F., editor (2016). Freshwater Fisheries Ecology. Wiley-Blackwell, Oxford, UK.

Dabrowska, K., Haider, W., and Hunt, L. (2014). Examining the impact of fisheries resources and quality on licence sales. Journal of Outdoor Recreation and Tourism, 5:58-67. https://doi.org/10.1016/j.jort.2014.03.005.

Dorow, M., Beardmore, B., Haider, W., and Arlinghaus, R. (2010). Winners and losers of conservation policies for European eel, Anguilla anguilla: an economic welfare analysis for differently specialised eel anglers. Fisheries Management and Ecology, 17(2):106-125. https://doi.org/10.1111/j.1365-2400.2009.00674.x.

Ensing, D. (2015). Pike (Esox lucius) could have been an exclusive human introduction to Ireland after all: a comment on Pedreschi et al.(2014). Journal of Biogeography, 42(3):604-607. https://doi.org/10.1111/jbi.12410.

FAO (2012). Technical Guidelines for Responsible Fisheries: Recreational Fisheries. Food and Agricultural Organization of the United Nations, Rome.

Fayram, A. H., Hansen, M. J., and Ehlinger, T. J. (2006). Influence of walleye stocking on angler effort in Wisconsin. Human Dimensions of Wildlife, 11(2):129-141. https://doi.org/10.1080/10871200600572540.

Ferrini, S. and Scarpa, R. (2007). Designs with a priori information for nonmarket valuation with choice experiments: A Monte Carlo study. Journal of Environmental Economics and Management, 53(3):342-363. https://doi.org/10.1016/j.jeem.2006.10.007.

Fisher, M. R. (1997). Segmentation of the angler population by catch preference, participation, and experience: a management-oriented application of recreation specialization. North American Journal of Fisheries Management, 17(1):1-10. https://doi.org/10.1577/15488675(1997)017<0001:SOTAPB >2.3.CO;2.

Fleming, C. M. and Bowden, M. (2009). Web-based surveys as an alternative to traditional mail methods. Journal of Environmental Management, 90(1):284-292. https://doi.org/10.1016/j.jenvman.2007.09.011.

Hilborn, R. (2007). Managing fisheries is managing people: what has been learned? Fish and Fisheries, 8(4):285-296. https://doi.org/10.1111/j.1467-2979.2007.00263_2.x.

Hunt, L. M., Gonder, D., and Haider, W. (2010). Hearing voices from the silent majority: a comparison of preferred fish stock- 
ing outcomes for Lake Huron by anglers from representative and convenience samples. Human Dimensions of Wildlife, 15(1):27-44. https://doi.org/10.1080/10871200903360080.

Hunt, L. M., Gonder, D., and Liskauskas, A. (2014). Dispelling common beliefs about angler opposition to lake trout (Salvelinus namaycush) rehabilitation efforts in Lake Huron. Journal of Great Lakes Research, 40(2):385-391. http://dx.doi.org/10.1016/j.jglr.2014.03.007.

Hutt, C. P. and Bettoli, P. W. (2007). Preferences, specialization, and management attitudes of trout anglers fishing in Tennessee tailwaters. North American Journal of Fisheries Management, 27(4):1257-1267. https://doi.org/10.1577/M05-215.1.

IFI (2014). Inland Fisheries Ireland Pike Policy. Inland Fisheries Ireland, Citywest, Dublin. http://www.fisheriesireland.ie/policies/455-inlandfisheries-ireland-pike-policy/file.

Johnston, F. D., Arlinghaus, R., and Dieckmann, U. (2013). Fish life history, angler behaviour and optimal management of recreational fisheries. Fish and Fisheries, 14(4):554-579. https://doi.org/10.1111/j.1467-2979.2012.00487.x.

Larsen, P. F., Hansen, M. M., Nielsen, E. E., Jensen, L., and Loeschcke, V. (2005). Stocking impact and temporal stability of genetic composition in a brackish northern pike population (Esox lucius L.), assessed using microsatellite DNA analysis of historical and contemporary samples. Heredity, 95(2):136-143. https://doi.org/10.1038/sj.hdy.6800671.

Lew, D. K. and Larson, D. M. (2014). Is a fish in hand worth two in the sea? evidence from a stated preference study. Fisheries Research, 157:124-135. https://doi.org/10.1016/j.fishres.2014.04.005.

Lewin, W.-C., Arlinghaus, R., and Mehner, T. (2006). Documented and potential biological impacts of recreational fishing: insights for management and conservation. Reviews in Fisheries Science, 14(4):305-367. https://doi.org/10.1080/10641260600886455.

Loomis, J. and Fix, P. (1998). Testing the importance of fish stocking as a determinant of the demand for fishing licenses and fishing effort in Colorado. Human Dimensions of Wildlife, 3(3):46-61. https://doi.org/10.1080/10871209809359131.

Lorenzen, K. (2005). Population dynamics and potential of fisheries stock enhancement: practical theory for assessment and policy analysis. Philosophical Transactions of the Royal Society B: Biological Sciences, 360(1453):171-189. https://doi.org/10.1098/rstb.2004.1570.

Lorenzen, K. (2008). Fish population regulation beyond "stock and recruitment": the role of density-dependent growth in the recruited stock. Bulletin of Marine Science, 83(1):181-196.

Madge, C. (2006). Advantages and disadvantages of online questionnaires. http://www.restore.ac.uk/orm/questionnaires/quesprint2.htm.

Marco-Rius, F., Sotelo, G., Caballero, P., and Morán, P. (2013). Insights for planning an effective stocking program in anadromous brown trout (Salmo trutta). Canadian Journal of Fisheries and Aquatic Sciences, 70(7):1092-1100. https://doi.org/10.1139/cjfas-2013-0084.

McFadden, D. (1973). Conditional logit analysis of qualitative choice behavior. In Zarenmbka, P., editor, Frontiers in Econometrics, pages $105-142$. Academic Press, New York.

McLachlan, G. and Peel, D. (2000). Finite Mixture Models. John Wiley \& Sons, Inc, New York.

Morris, A. (2007). E-literacy and the grey digital divide: a review with recommendations. Journal of Information Literacy, 1(3):13-28. https://doi.org/10.11645/1.3.14.

Oh, C.-O. and Ditton, R. B. (2006). Using recreation specialization to understand multi-attribute management preferences. Leisure Sciences, 28(4):369-384. https://doi.org/10.1080/01490400600745886.

Oh, C.-O., Ditton, R. B., Gentner, B., and Riechers, R. (2005). A stated preference choice approach to understanding angler preferences for management options. Human dimensions of wildlife, 10(3):173-186. https://doi.org/10.1080/10871200591003427.

Olaussen, J. O. and Liu, Y. (2011). On the willingness-to-pay for recreational fishing-escaped farmed versus wild Atlantic salmon. Aquaculture Economics \& Management, 15(4):245-261. https://doi.org/10.1080/13657305.2011.624573.

Parsons, G. R. and Massey, D. M. (2003). A random utility model of beach recreation. In Hanley, N., Shaw, W. D., and Wright, R. E., editors, The New Economics of Outdoor Recreation, pages 241-267. Edward Elgar, Cheltenham.

Patrick, W. S., Bin, O., Schwabe, K. A., and Schuhmann, P. W. (2006). Hatchery programs, stock enhancement, and cost effectiveness: a case study of the Albemarle Sound/Roanoke River stocking program 1981-1996. Marine Policy, 30(4):299-307. https://doi.org/10.1016/j.marpol.2005.02.003.

Patterson, W. F. and Sullivan, M. G. (2013). Testing and refining the assumptions of put-and-take rainbow trout fisheries in Alberta. Human Dimensions of Wildlife, 18(5):340-354. https://doi.org/10.1080/10871209.2013.809827.

Pedreschi, D., Kelly-Quinn, M., Caffrey, J., O'Grady, M., and Mariani, S. (2014). Genetic structure of pike (Esox lucius) reveals a complex and previously unrecognized colonization history of Ireland. Journal of biogeography, 41(3):548-560. https://doi.org/10.1111/jbi.12220.

Post, J. (2013). Resilient recreational fisheries or prone to collapse? a decade of research on the science and management of recreational fisheries. Fisheries Management and Ecology, 20(2-3):99-110. https://doi.org/10.1111/fme.12008.

Pradhan, N. C. and Leung, P. (2004). Modeling trip choice behavior of the longline fishers in Hawaii. Fisheries Research, 68(1):209-224. https://doi.org/10.1016/j.fishres.2003.12.006.

Provencher, B. and Bishop, R. C. (2004). Does accounting for preference heterogeneity improve the forecasting of a random utility model? a case study. Journal of Environmental Economics and Management, 48(1):793-810. https://doi.org/10.1016/j.jeem.2003.11.001.

Ready, R., Epp, D., and Delavan, W. (2005). A comparison of revealed, stated, and actual behavior in response to a change in fishing quality. Human Dimensions of Wildlife, 10(1):39-52. https://doi.org/10.1080/10871200590904879.

Scarpa, R. and Rose, J. M. (2008). Design efficiency for non-market valuation with choice modelling: how to measure it, what to report and why. Australian Journal of Agricultural and Resource Economics, 52(3):253-282. https://doi.org/10.1111/j.1467-8489.2007.00436.x.

Schaufler, G., Stögner, C., Gassner, H., Kaiser, R., and Schabetsberger, R. (2015). How to contain a tapeworm epidemic-testing the efficiency of different catch methods to reduce the translocated final host Esox lucius in an alpine lake. International Review of Hydrobiology, 100(5-6):169176. https://doi.org/10.1002/iroh.201401782.

Schultz, R. D. and Dodd, B. J. (2008). Characteristics of an Iowa put-and-take rainbow trout fishery and associated economic benefits. In Eades, R. T., Neal, J. W., Lang, T. J., Hunt, K. M., and Pajak, P., editors, Urban and community fisheries programs: development, management, and evaluation, pages 391-401. American Fisheries Society.

Siderelis, C., Brothers, G., and Rea, P. (1995). A boating choice model for the valuation of lake access. Journal of Leisure Research, $27(3): 264$.

Støttrup, J. and Sparrevohn, C. R. (2007). Can stock enhancement enhance stocks? Journal of Sea Research, 57(2):104-113. https://doi.org/10.1016/j.seares.2006.09.005 
Socio-Economic Study of Recreational Angling in Ireland.

Inland Fisherie

Ireland. http://www.fisheriesireland.ie/media/tdistudyonrecreationalangling.pdf.

Teisl, M. F., Boyle, K. J., and Roe, B. (1996). Conjoint analysis of angler evaluations of Atlantic salmon restoration on the Penobscot River, Maine. North American Journal of Fisheries Management, 16(4):861-871. https://doi.org/10.1577/1548-8675(1996)016<0861:CAOAEO>2.3.CO;2.

Thuesen, P., Russell, D., Thomson, F., Pearce, M., Vallance, T., and Hogan, A. (2011). An evaluation of electrofishing as a control measure for an invasive tilapia (Oreochromis mossambicus) population in northern Australia. Marine and Freshwater Research, 62(2):110-118. https://doi.org/10.1071/MF10057.

Train, K. E. (2009). Discrete Choice Methods with Simulation. Cambridge University Press, New York, USA.

Viney, M. (2015). Another life: Our pike are noble predators, not alien villains.

The Irish Times. http://www.irishtimes.com/news/environment/another-life-our-pike-are-noble-predators-not-alien-villains-1.2152970

Whitehead, J. C., Dumas, C. F., Landry, C. E., and Herstine, J. (2011). Valuing bag limits in the North Carolina charter boat fishery with combined revealed and stated preference data. Marine Resource Economics, 26(3):233-241. https://doi.org/10.5950/0738-1360-26.3.233.

Wilen, J. E., Smith, M. D., Lockwood, D., and Botsford, L. W. (2002). Avoiding surprises: incorporating fisherman behavior into management models. Bulletin of Marine Science, 70(2):553-575. 